\title{
The Fernow Experimental Forest, West Virginia, USA: Insights, datasets, and opportunities.
}

\author{
Luis Andrés Guillén ${ }^{1}$, Mary Beth Adams ${ }^{2}$, Emily Elliott ${ }^{3}$, Jason Hubbart ${ }^{1}$, Charlene \\ Kelly $^{1}$, Brenden McNeil ${ }^{1}$, William Peterjohn ${ }^{1}$, and Nicolas Zegre ${ }^{1,1}$ \\ ${ }^{1}$ West Virginia University \\ ${ }^{2}$ USDA Forest Service Northern Research Station \\ ${ }^{3}$ University of Pittsburgh
}

August 10, 2020

\begin{abstract}
Long-term experimental watershed studies have significantly influenced our global understanding of hydrological processes. The discovery and characterization of how stream water quantity and quality respond to a changing environment (e.g., land use change and acidic deposition) has only been possible due to the establishment of catchments devoted to long-term study. One such catchment is the Fernow Experimental Forest (FEF) located in the headwaters of the Appalachian Mountains in West Virginia, a region that provides essential freshwater ecosystem services to eastern and mid-western USA communities. Established in 1934, the FEF is among the earliest experimental watershed studies in the Eastern USA that continues to address emergent challenges to forest ecosystems, including climate change and other threats to forest health. This data note summarizes some of the seminal findings from more than 50 years of hydrologic research in the FEF. During the first few decades, research at the FEF focused on the relationship between forest management and hydrological processes - especially those related to the overall water balance. Later, research efforts included the examination of interactions between hydrology and soil erosion, biogeochemistry, N-saturation, and acid deposition. Hydro-climatologic and water quality datasets from longterm measurements and data from short-duration studies are publicly available to provide new insights and foster collaborations that will continue to advance our understanding of hydrology in forested headwater catchments. As a result of its rich history of research and abundance of long-term data, the FEF is uniquely positioned to continue to advance understanding of forest ecosystems in a time of unprecedented change.
\end{abstract}

Title page:

i. Title:

The Fernow Experimental Forest, West Virginia, USA: Insights, datasets, and opportunities.

ii. Running head:

The Fernow Experimental Forest.

iii. Full Names of the Authors and iv. Institutions:

Luis Andrés Guillén * (Corresponding author), Division of Forestry \& Natural Resources, West Virginia University, 334 Percival Hall, Morgantown, WV 26506, USA, lg0018@mix.wvu.edu

Mary Beth Adams, PhD. Research Soil Scientist, USDA Forest Service Northern Research Station.

Emily Elliot, PhD. Associate Professor, Department of Geology and Environmental Science, University of Pittsburgh. 
Jason Hubbart, PhD. Professor, Division of Plant and Soil Sciences \& Division of Forestry and Natural Resources, West Virginia University.

Charlene Kelly, PhD. Teaching Assistant Professor. Division of Forestry \& Natural Resources, West Virginia University.

Brenden McNeil, PhD. Associate Professor. Department of Geography, West Virginia University.

William Peterjohn, PhD. Professor. Department of Biology, West Virginia University.

Nicolas Zegre, PhD. Associate Professor. Division of Forestry \& Natural Resources, West Virginia University.

v. Acknowledgements:

An immeasurable debt of gratitude is due to the early USDA Forest Service scientists who designed and implemented many of the studies at the FEF - their names can be found in the list of references. Equally important are the generations of field and lab technicians who assured that this research was conducted carefully and consistently: Bud Fridley, John Campbell, Doug Owens, Clifford Phillips, Melvin Owens, Chris Cassidy, Emmett Fox, John Pierce, Cheryl Wiles, and Frederica Wood, who has served as the data manager for the Fernow. Funding for this research was provided, in part, by the Long Term Research in Environmental Biology (LTREB) program at the National Science Foundation (Grant Nos. DEB0417678 and DEB-1019522) to West Virginia University; and by the National Science Foundation (Grant Nos OIA-148952) and the USDA National Institute of Food and Agriculture Hatch project (Grant Nos 1004360), both to Zegre.

Keywords:

Long-term datasets, Forest Management, Fernow Experimental Forest, Experimental Catchments, Hydrological Processes.

Abstract:

Long-term experimental watershed studies have significantly influenced our global understanding of hydrological processes. The discovery and characterization of how stream water quantity and quality respond to a changing environment (e.g., land use change and acidic deposition) has only been possible due to the establishment of catchments devoted to long-term study. One such catchment is the Fernow Experimental Forest (FEF) located in the headwaters of the Appalachian Mountains in West Virginia, a region that provides essential freshwater ecosystem services to eastern and mid-western USA communities. Established in 1934, the FEF is among the earliest experimental watershed studies in the Eastern USA that continues to address emergent challenges to forest ecosystems, including climate change and other threats to forest health. This data note summarizes some of the seminal findings from more than 50 years of hydrologic research in the FEF. During the first few decades, research at the FEF focused on the relationship between forest management and hydrological processes - especially those related to the overall water balance. Later, research efforts included the examination of interactions between hydrology and soil erosion, biogeochemistry, N-saturation, and acid deposition. Hydro-climatologic and water quality datasets from long-term measurements and data from short-duration studies are publicly available to provide new insights and foster collaborations that will continue to advance our understanding of hydrology in forested headwater catchments. As a result of its rich history of research and abundance of long-term data, the FEF is uniquely positioned to continue to advance understanding of forest ecosystems in a time of unprecedented change.

Main text:

\section{The Fernow Experimental Forest}

Long-term research in small gauged forested watersheds within the USDA Forest Service Experimental Forest and Range network (USDA-EFR) has contributed substantially to current management of forests (Vose et al., 2012). In 1934, the USDA Forest Service Fernow Experimental Forest (FEF) was established to study mixed hardwood silviculture practices of the Appalachian Mountain region. FEF is located in Tucker County, West Virginia $\left(39^{\circ} 03^{\prime} \mathrm{N}, 79^{\circ} 40^{\prime} \mathrm{W}\right)$ within the Monongahela National Forest. Elevation ranges from 
706 - $843 \mathrm{~m}$. As part of the USDA-EFR network, FEF has contributed to many comparative studies (e.g. Vose et al., 2012; Amatya et al., 2016), and research from the FEF has produced numerous publications that assess the impacts of forest management on ecosystem processes (Hornbeck et al., 1993) and water quality. Additionally, ecosystem responses to the chronic chemical stressors have been the subject of both long-term acidification experiments (Adams et al., 2006) and observational studies of ecosystem responses to nitrogen saturation (Stoddard, 1994; Peterjohn et al., 1996; Rose et al., 2015). In this data note, we summarize some of the seminal findings from 50+ years of hydrological research at the FEF. Hydro-climatologic and water quality datasets are presented that represent long-term monitoring and short duration studies; we conclude with opportunities for scientific collaboration and data sharing that will advance forest management and hydrologic understanding.

FEF's mean annual air temperature is $9.3^{\circ} \mathrm{C}$ while mean monthly temperatures range from $-2.8{ }^{\circ} \mathrm{C}$ in January to $20.4{ }^{\circ} \mathrm{C}$ in July (Adams et al., 2012). In the last 60 years the mean annual air temperature increased $0.01{ }^{\circ} \mathrm{C} \mathrm{yr}^{-1}$, with minimum temperature increasing $0.02{ }^{\circ} \mathrm{C} \mathrm{yr}^{-1}$ and the maximum temperature remaining relatively constant (Young et al., 2019). Mean annual precipitation is $1458 \mathrm{~mm}$ (Adams et al., 2012) and is distributed evenly throughout the year. The precipitation regime has been relatively constant during the last 60 years (Young et al., 2019). Growing season precipitation is associated with convectional thunderstorms while dormant season precipitation is associated with frontal systems (Adams et al., 2012). Stream discharge $\left(\mathrm{m}^{3} / \mathrm{s}\right)$ is dominated by baseflow with flashy storm flow occurring rapidly after precipitation events. Mean annual runoff $(\mathrm{mm})$ in the reference watershed (WS 4) is $642 \mathrm{~mm}$ and evapotranspiration averages $816 \mathrm{~mm}$, indicating that $56 \%$ of the rainfall in WS4 returns to the atmosphere as evapotranspiration. Vegetation at the FEF is dominated by mixed mesophytic forest, including over 500 hundred species of vascular plants (Madarish et al., 2002). Common overstory species include red oak (Quercus rubra), sugar maple (Acer saccharum ), yellow poplar (Liriodendron tulipifera), black cherry (Prunus serotina) and other broadleaf Appalachian Forest species (Madarish et al., 2002). Soils are shallow ( $<1 \mathrm{~m}$ ), loamy-skeletal, and well-drained with steep slopes averaging 16\% (Adams et al. 2012). FEF has 10 gauged watersheds (Figure 1) including three reference (WS 4, 10 and 13 established in 1951, 1988, and 1993 respectively), one conversion from broadleaved forest to a Norway spruce (Picea abies ) stand in 1973 (WS 6), and one (WS 3) that has been fertilized/acidified from 1989-2020. The remaining have been disturbed by varying degrees of harvesting practices (WS 2, 5, 7). Watershed 14 contains WS 6, 7 and 13 (Figure 1).

[Insert Figure 1 here]

\section{FEF contributions to scientific understanding of hydrological processes}

\section{Land cover and management effects on water yield}

Prior to 1980, hydrological research was focused on understanding the effects of forest management practices on streamflow, namely water yield. Extended droughts in the eastern US in the early 1960's drove inquiry into water yield from forested watersheds, propelling studies investigating harvest and herbicide applications (Kochenderfer et al., 1990). Clearcutting experiments (WS 3, 6 and 7) were undertaken to advance understanding of energy and water budgets (Hornbeck et al., 1993; Tajchman et al., 1997). FEF research advanced understanding of the influence of species composition on water yield by documenting a significant reduction in streamflow following conversion of broadleaf temperate forest to Norway spruce (Adams et al., 2012) (Figure 2). More recent research focused on how climate change influences the water balance (Creed et al., 2014; Jones et al., 2012; Vadeboncoeur et al., 2018; Young et al., 2019); altered rates of evapotranspiration due to ecosystem acidification (Lanning et al., 2019), and other effects of air pollution on the water use efficiency of broadleaf deciduous species through dendroisotopic approaches (Mathias, 2020).

[Insert Figure 2 here]

\section{Land cover, management, and pollution effects on water quality}

Understanding what is in the water has also been a central research theme at the FEF. Erosion and sedimentation assessments of land management practices have been important since the initial research (Hornbeck \& 
Reinhart 1964). Monitoring of stream-water chemistry began in 1958 for some analytes but more extensive assessments were initiated in the 1970's (Patric \& Smith, 1978) and especially in the period from 1980 2000 following improvements in lab facilities and the start of a whole-watershed acidification study in 1989 (reviewed in Adams et al., 2006) (Figure 3). Through studies of stream chemistry, FEF research has advanced understanding of how past land-use practices (legacy effects), the composition of tree species (Peterjohn et al. 2015), and acid deposition have affected ecosystem processes (Edwards et al., 2002).

[Insert Figure 3 here]

\section{Legacy of FEF science on governmental policies}

Research at FEF has improved forest management policies in eastern US deciduous forests, including regional best management practices (BMPs), such as minimizing road construction impacts on erosion and sedimentation (Kochenderfer, 1970) and protocols to test the efficacy of the BMPs (Ryder \& Edwards, 2005). It has also documented the effects of regional air pollution on forests and the effectiveness of Federal policies to reduce its impacts. There is no doubt that continuing monitoring and long-term experiments in the FEF is crucial for the ongoing improvement of policies aimed at maintaining a resilient ecosystem.

\section{Available Data:}

Core datasets of the FEF include long-term hydro-climatological data for five gauged watersheds, with measurements starting in 1951. Five watersheds were added later. Daily time series of air temperature, precipitation, streamflow, and biweekly precipitation and stream chemistry data are publicly available from the Forest Service [https://www.nrs.fs.fed.us/ef/locations/wv/fernow/data/]. Data are quality-controlled and curated by the FEF data manager. Growing season (June - October) soil moisture measurements for surface $(0-5 \mathrm{~cm})$ mineral soils in WS 3, 4, and 7 are available for 2007-2019 [http://www.as.wvu.edu/fernow/data.html]. Also available are almost three decades (1964 - 1991) of pan evapotranspiration data sampled daily during the growing season (April to September/October). FEF is a member of several national environmental monitoring networks: Climate and Hydrology Database Projects (CLIMDB/HYDRODB) [https://climhy.lternet.edu/] focused on long-term meteorological and streamflow records; Smart Forest [http://smartforests-data.sr.unh.edu/data/gce/Fernow/data/] a network of digital, high frequency and real-time environmental data; and the National Atmospheric Deposition Program (NADP) [http://nadp.slh.wisc.edu/data/sites/siteDetails.aspx?net=NTN\&id=WV18] and Clean Air Status and Trends Networks (CASTNET) [https://www3.epa.gov/castnet/site_pages/PAR207.html] which provide some of the longest records of wet and dry deposition in the U.S., respectively. For 15 years, research at the FEF has been supported by the NSF LTREB (Long Term Research in Environmental Biology) program, which has resulted in important data contributions on the whole-watershed acidification and LongTerm Soil Productivity experiments [http://www.as.wvu.edu/fernow/data.html]. Associated metadata can be found in the aforementioned references and websites. Finally, data from short-duration studies at the FEF are also available including sapflow in WS4 (growing seasons 2017 and 2018), and a growing database of hyperspectral and hyper-spatial resolution remote sensing datasets (e.g. Fang et al., 2018; Singh et al., 2015).

\section{Future Directions}

Advancing forest ecosystem management is a major challenge for this century and an imperative for the future sustainability of forest and water resources (Ellison et al., 2017). Moreover, current and future environmental and societal challenges (e.g. climate change; novel diseases; population growth; megadisturbances; and environmental justice) require open data science approaches and higher levels of collaboration. Forested uplands have long been relied upon as sources of clean water, while at the same time suffering from resource extraction and environmental pollution. Therefore, FEF encourages future research and collaboration that propels science-based information to protect water flow regimes and water quality, while maintaining other important ecosystem and economic services like timber production and recreation. Future research avenues may include: i) Linking hydrology and nutrient cycling within a catchment - Ecohydrological coupling and separation (i.e. testing the "two-water worlds" hypothesis (Berry et al., 2018) and its implications for water 
quality); ii) Studying water balance dynamics over time, focusing on storage (soil moisture) and evapotranspiration (sapflow and interception); iii) Linking documented changes in forest composition to present and future susceptibility to drought/climate change (building on Young et al. 2019); iv) Understanding recovery from ecosystem acidification (following cessation of fertilizer additions to WS 3 in 2021); and v) Use of long-term records and Empirical Dynamic Modeling (Sugihara et al., 2012) to explore the causal influence of environmental change and vegetation productivity (using tree-ring records) on hydrology and ecosystem structure (e.g. Watson, 2018). Building on the substantial outcomes of past research that shaped hydrologic management (Vose et al., 2012) and silvicultural practices (Barrett, 1995) of the Appalachian Mountain region, a strategic plan for future research will provide the critically needed knowledge on the interactions between climate, streamflow, and forest management practices that will usher in a new era of forest ecosystem management in Appalachia and beyond.

\section{References}

Adams, M. B., DeWalle, D. R., \& Hom, J. L. (Eds.). (2006). The Fernow Watershed Acidification Study . Springer Netherlands. https://doi.org/10.1007/978-1-4020-4615-5

Adams, M. B., Edwards, P. J., Ford, W. M., Schuler, T.M., Thomas-Van Gundy, M., \& Wood, F. (2012). Fernow experimental forest: Research history and opportunities. U.S. Department of Agriculture, Forest Service.

Amatya, D., Campbell, J., Wohlgemuth, P., Elder, K., Sebestyen, S., Johnson, S., Keppeler, E., Adams, M. B., Caldwell, P., \& Misra, D. (2016). Hydrological processes of reference watersheds in Experimental Forests, USA. In D. M. Amatya (Ed.), Forest Hydrology: Processes, Management and Assessment (pp. 219-239). CAB International and USDA.

Barrett, J.W. (1995). Regional silviculture of the United States(3rd ed.). John Wiley \& Sons.

Berry, Z. C., Evaristo, J., Moore, G., Poca, M., Steppe, K., Verrot, L., Asbjornsen, H., Borma, L. S., Bretfeld, M., Hervé-Fernandez, P., Seyfried, M., Schwendenmann, L., Sinacore, K., Wispelaere, L. D., \& McDonnell, J. (2018). The two water worlds hypothesis: Addressing multiple working hypotheses and proposing a way forward.Ecohydrology , 11 (3), e1843. https://doi.org/10.1002/eco.1843

Creed, I. F., Spargo, A. T., Jones, J. A., Buttle, J. M., Adams, M. B., Beall, F. D., Booth, E. G., Campbell, J. L., Clow, D., Elder, K., Green, M. B., Grimm, N. B., Miniat, C., Ramlal, P., Saha, A., Sebestyen, S., Spittlehouse, D., Sterling, S., Williams, M. W., .. Yao, H. (2014). Changing forest water yields in response to climate warming: Results from long-term experimental watershed sites across North America. Global Change Biology , 20 (10), 3191-3208. https://doi.org/10.1111/gcb.12615

Edwards, P. J., Wood, F., \& Kochenderfer, J. N. (2002). Baseflow and peakflow chemical responses to experimental applications of ammonium sulphate to forested watersheds in north-central West Virginia, USA.Hydrological Processes , 16 (12), 2287-2310. https://doi.org/10.1002/hyp.1000

Ellison, D., Morris, C. E., Locatelli, B., Sheil, D., Cohen, J., Murdiyarso, D., Gutierrez, V., Noordwijk, M. van, Creed, I. F., Pokorny, J., Gaveau, D., Spracklen, D. V., Tobella, A. B., Ilstedt, U., Teuling, A. J., Gebrehiwot, S. G., Sands, D. C., Muys, B., Verbist, B., .. Sullivan, C. A. (2017). Trees, forests and water: Cool insights for a hot world. Global Environmental Change , 43 , 51-61. http://dx.doi.org/10.1016/j.gloenvcha.2017.01.002

Fang, F., McNeil, B. E., Warner, T. A., \& Maxwell, A. E. (2018). Combining high spatial resolution multi-temporal satellite data with leaf-on LiDAR to enhance tree species discrimination at the crown level.International Journal of Remote Sensing , 39 (23), 9054-9072. https://doi.org/10.1080/01431161.2018.1504343

Hornbeck, J. W., Adams, M. B., Corbett, E. S., Verry, E. S., \& Lynch, J. A. (1993). Long-term impacts of forest treatments on water yield: A summary for northeastern USA. Journal of Hydrology ,150 (2-4), 323-344. https://doi.org/10.1016/0022-1694(93)90115-P 
Hornbeck, J.W, \& Reinhart, K.G. (1964). Water quality and soil erosion as affected by logging in steep terrain. Journal of Soil and Water Conservation, 1 (19), 23-27.

Jones, J. A., Creed, I. F., Hatcher, K. L., Warren, R. J., Adams, M. B., Benson, M. H., Boose, E., Brown, W. A., Campbell, J. L., Covich, A., Clow, D. W., Dahm, C. N., Elder, K., Ford, C. R., Grimm, N. B., Henshaw, D. L., Larson, K. L., Miles, E. S., Miles, K. M., ... Williams, M. W. (2012). Ecosystem Processes and Human Influences Regulate Streamflow Response to Climate Change at Long-Term Ecological Research Sites.Bioscience, 62 (4), 390-404. https://doi.org/10.1525/bio.2012.62.4.10

Kochenderfer, J. N. (1970). Erosion control on logging roads in the Appalachians. Res. Pap. NE-158. Upper Darby, PA: U.S. Department of Agriculture, Forest Service, Northeastern Forest Experiment Station. 28 p. , 158 . https://www.fs.usda.gov/treesearch/pubs/23767

Kochenderfer, J. N., Edwards, P. J., \& Helvey, J. D. (1990). Land management and water yield in the Appalachians. Proceedings of the Symposium on Watershed Planning and Analysis in Action; Conference Date: 09-07-1990 Through 11-07-1990", 523-532.

Lanning, M., Wang, L., Scanlon, T. M., Vadeboncoeur, M. A., Adams, M. B., Epstein, H. E., \& Druckenbrod, D. (2019). Intensified vegetation water use under acid deposition. Science Advances , 5 (7), eaav5168. https://doi.org/10.1126/sciadv.aav5168

Madarish, D. M., Rodrigue, J. L., \& Adams, M. B. (2002). Vascular flora and macroscopic fauna on the Fernow Experimental Forest(NE-GTR-291; p. NE-GTR-291). U.S. Department of Agriculture, Forest Service, Northeastern Research Station. https://doi.org/10.2737/NE-GTR-291

Mathias, J. (2020). Tree growth and water use efficiency during the twentieth century: From global trends to local drivers. Graduate Theses, Dissertations, and Problem Reports . https://doi.org/10.33915/etd.7610

Patric, J. H., \& Smith, D. W. (1978). Some effects of urea fertilization on forested watershed in West Virginia. In: Proceedings: Central hardwood conference II . 210-227.

Peterjohn, W. T., Adams, M. B., \& Gilliam, F. S. (1996). Symptoms of nitrogen saturation in two central Appalachian hardwood forest ecosystems. Biogeochemistry , 35 (3), 507-522. https://doi.org/10.1007/BF02183038

Peterjohn, W.T., M.A. Harlacher, M.J. Christ, and M.B. Adams (2015) Testing associations between tree species and nitrate availability: Do consistent patterns exist across spatial scales? Forest Ecology and Management 358:335-343

Rose, L. A., Elliott, E. M., \& Adams, M. B. (2015). Triple Nitrate Isotopes Indicate Differing Nitrate Source Contributions to Streams Across a Nitrogen Saturation Gradient. Ecosystems , 18 (7), 1209-1223. JSTOR.

Ryder, R., \& Edwards, P. J. (2005). Development of a Repeatable Regional Protocol for PerformanceBased Monitoring of Forestry Best Management Practices. Gen. Tech. Rep. NE-335. Newtown Square, PA: U.S. Department of Agriculture, Forest Service, Northeastern Research Station. 15 p. , 335 . https://doi.org/10.2737/NE-GTR-335

Singh, A., Serbin, S. P., McNeil, B. E., Kingdon, C. C., \& Townsend, P. A. (2015). Imaging spectroscopy algorithms for mapping canopy foliar chemical and morphological traits and their uncertainties.Ecological Applications , 25 (8), 2180-2197. https://doi.org/10.1890/14-2098.1

Stoddard, J. L. (1994). Long-Term Changes in Watershed Retention of Nitrogen. In Environmental Chemistry of Lakes and Reservoirs(Vol. 237, pp. 223-284). American Chemical Society. https://doi.org/10.1021/ba-1994-0237.ch008

Sugihara, G., May, R., Ye, H., Hsieh, C., Deyle, E., Fogarty, M., \& Munch, S. (2012). Detecting Causality in Complex Ecosystems.Science, 338 (6106), 496-500. https://doi.org/10.1126/science.1227079 
Tajchman, S. J., Fu, H., \& Kochenderfer, J. N. (1997). Water and energy balance of a forested Appalachian watershed. Agricultural and Forest Meteorology , 84 (1), 61-68. https://doi.org/10.1016/S01681923(96)02375-1

Vadeboncoeur, M. A., Green, M. B., Asbjornsen, H., Campbell, J. L., Adams, M. B., Boyer, E. W., Burns, D. A., Fernandez, I. J., Mitchell, M. J., \& Shanley, J. B. (2018). Systematic variation in evapotranspiration trends and drivers across the Northeastern United States.Hydrological Processes , 32 (23), 3547-3560. https://doi.org/10.1002/hyp.13278

Vose, J. M., Ford, C. R., Laseter, S., Dymond, S., Sun, G., Adams, M. B., Sebestyen, S., Campbell, J., Luce, C., Amatya, D., Elder, K., \& Heartsill-Scalley, T. (2012). Can forest watershed management mitigate climate change effects on water resources? In Webb, Ashley A., Bonell, Mike, Bren, Leon, Lane, Patrick N. J., \& et. al. (Eds.), Revisiting Experimental Catchment Studies in Forest Hydrology, Proceedings of a Workshop held during the XXV IUGG General Assembly in Melbourne, June-July 2011 (pp. 12-25). IAHS Publ.

Watson, J. V. (2018). Exploring Forest Diversity and Ecosystem Services Using Big Data and Empirical Dynamic Modeling [PhD, West Virginia University Libraries]. https://doi.org/10.33915/etd.7297

Young, D., Zegre, N., Edwards, P., \& Fernandez, R. (2019). Assessing streamflow sensitivity of forested headwater catchments to disturbance and climate change in the central Appalachian Mountains region, USA.Science of The Total Environment , 694 , 133382. https://doi.org/10.1016/j.scitotenv.2019.07.188

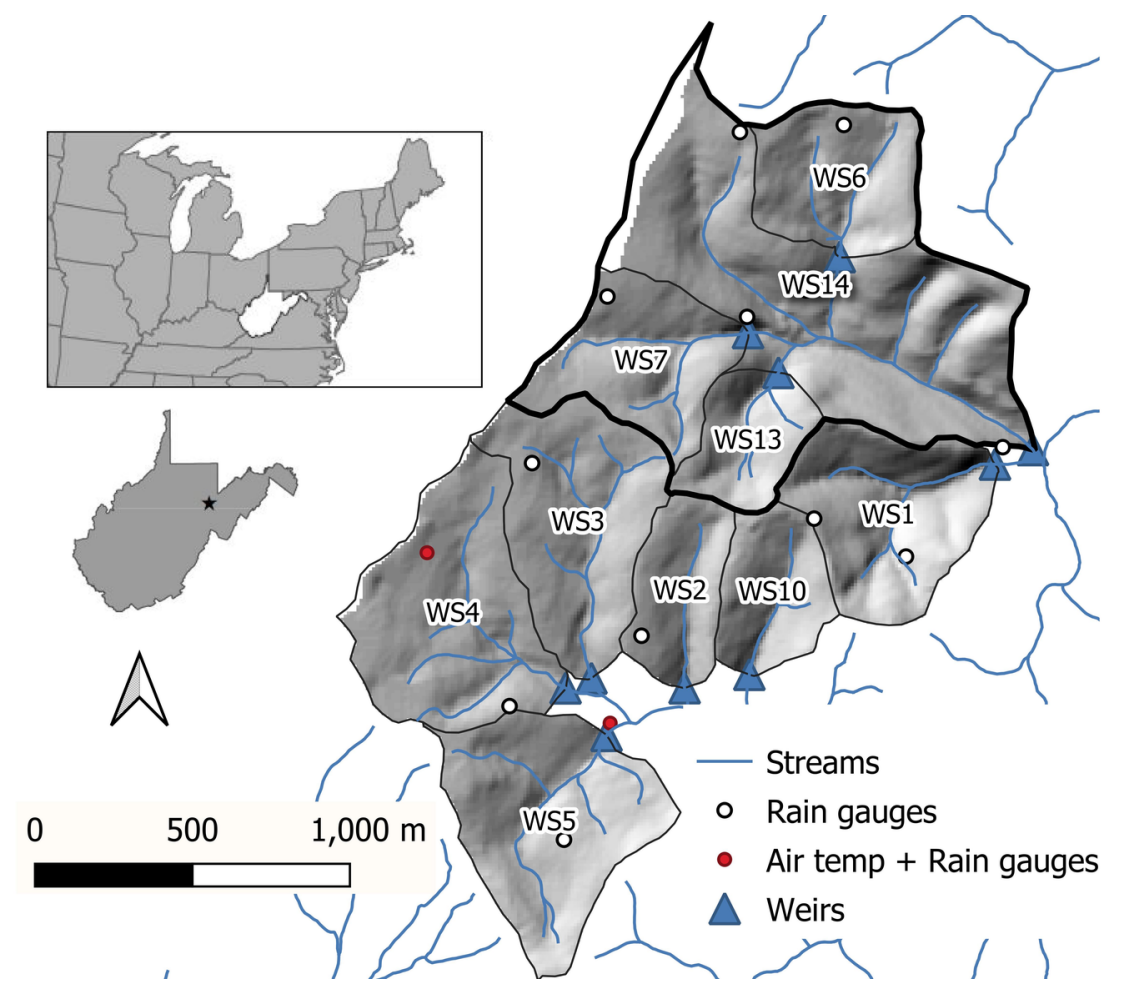



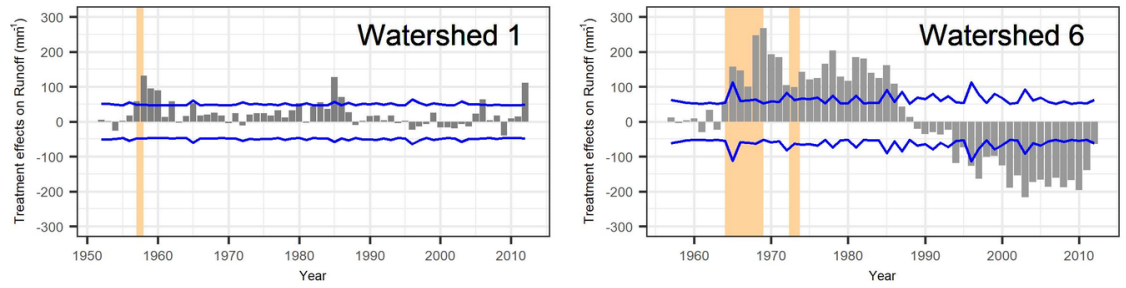

Treatment $\quad-95 \%$ Prediction limits
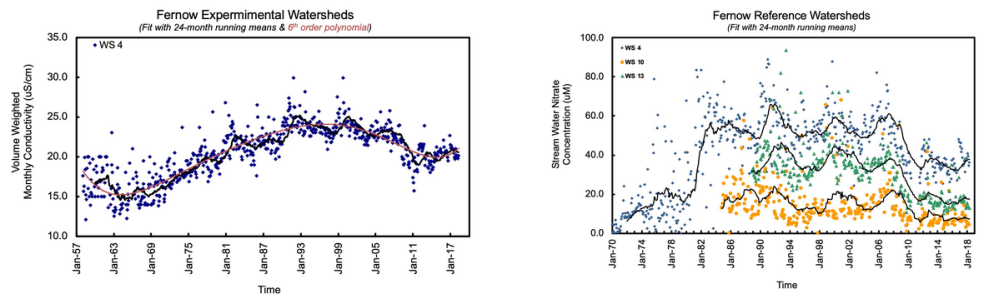